ORIGINAL ARTICLE / ARTIGO ORIGINAL

\title{
Elderly victims of falls seen by prehospital care: gender differences
}

\author{
Idosos vitimas de quedas atendidos por serviços pré-hospitalares: \\ diferenças de gênero
}

\author{
William Campo Meschial', Dorotéia Fátima Pelissari de Paula Soares', Nelson Luiz Batista \\ de Oliveira', Alice Milani Nespollo', Wesley Alexandre da Silva", Fernando Luiz de Paula Santil"'I
}

\begin{abstract}
Objective: To identify elderly who are victims of falls, according to gender, who received care from prehospital services of Maringá, Paraná. Methods: A cross-sectional exploratory study carried out with 1,444 elderly patients who suffered falls in Maringá in the period from 2006 to 2008. Data were gathered from prehospital care services, typed and processed using the Epi Info $6.04 \mathrm{~d}^{\circledR}$. The $\chi^{2}$ test was used to compare the falls in relation to gender (significance level $=0.05$ ). Results: The number of falls according to gender presented similar percentages, $51.0 \%$ for males and $49.0 \%$ for females. Significant differences between genders were observed regarding age $(p<0.001)$, presence of alcohol breath $(p<0.001)$, type of fall $(p<0.001)$, place of fall $(p<0.001)$, treatment at hospital $(p=0.023)$, number of injuries $(p=0.014)$, type of injury $(p<0.001)$ and injury location $(\mathrm{p}<0.001)$. Conclusion: These results show that falls happen differently among the elderly when considering gender. It highlights the importance of understanding these differences in detail and the circumstances in which the fall occurred, since this knowledge is key to plan preventive actions.
\end{abstract}

Keywords: Aged. Accidental falls. Gender identity. Emergency relief. Epidemiology. External causes.

'Departamento de Enfermagem, Universidade Estadual de Maringá - Maringá (PR), Brasil.

"Departamento de Geografia, Universidade Federal do Paraná - Curitiba (PR). Brasil.

"'Instituto de Geografia da Universidade Federal de Uberlândia - Monte Carmelo (MG), Brasil.

Corresponding author: Dorotéia Fátima Pelissari de Paula Soares. Avenida Colombo, 5790, Jd. Universitário, CEP: 87020-900,

Maringá, PR, Brasil. E-mail: dfppsoares@uem.br

Conflict of interests: nothing to declare - Financial Support: National Counsel of Technological and Scientific Development (CNPq) (Process No477924/2009-3, Edital MCT/CNPq no 14/2009 - Universal). 
RESUMO: Objetivo: Identificar os idosos vítimas de quedas, segundo o gênero, atendidos por serviços pré-hospitalares do município de Maringá, PR. Metodologia: Estudo transversal exploratório, realizado com 1444 idosos que sofreram quedas no município de Maringá no período de 2006 a 2008. Os dados foram coletados dos serviços de atendimento pré-hospitalares, digitados e processados no programa Epi Info 6.04d ${ }^{\circledR}$. Foi utilizado o teste do $\chi^{2}$ com nível de significância de 0,05 para comparação das quedas em relação ao gênero. Resultados: A ocorrência de queda em relação ao gênero apresentou percentuais próximos, 51,0\% no gênero masculino e 49,0\% no feminino. Foram observadas diferenças significativas entre os gêneros para a faixa etária $(\mathrm{p}<0,001)$, presença de hálito etílico $(\mathrm{p}<0,001)$, tipo de queda $(\mathrm{p}<0,001)$, local da queda $(p<0,001)$, encaminhamento ao hospital $(p=0,023)$, número de lesões $(p=0,014)$, tipo de lesão $(p<0,001)$ e localização da lesão $(\mathrm{p}<0,001)$. Conclusão: Estes resultados indicam que as quedas ocorrem de forma diferente entre os idosos quando se considera o gênero. Destacam, também, a importância de conhecer estas diferenças de forma mais aprofundada e as circunstâncias em que ocorreram as quedas, visto que este conhecimento é fundamental no planejamento de ações preventivas.

Palavras-chave: Idoso. Acidentes por quedas. Identidade de gênero. Socorro de urgência. Epidemiologia. Causas externas.

\section{INTRODUCTION}

Due to the demographic transition characterized by the decreased fecundity and increased life expectancy, Brazil has been going through changes in the age structure, therefore reflecting on the reduced proportion of children and young people and the increased adult and elderly population ${ }^{1}$. Such a process, known as population aging, has a major influence on the spheres of social, economic, political and cultural structure of society, since the elderly, as well as the other age groups (children, young people and adults), presented specific demands for dignifying life conditions ${ }^{2}$.

Aging comes with physical and mental health problems, often caused by chronic conditions and falls ${ }^{3}$, and the latter, due to the high frequency with which they affect this age group, constitute an important determining factor for the health of the elderly person.

According to the $10^{\text {th }}$ revision of the International Classifications of Diseases (ICD-10), falls are considered to be an external cause ${ }^{4}$. It is defined as an "accidental event resulting from the changing position of an individual to a lower level in relation to the position he or she was in initially"s.

Generally, the risk of falls is present among all ages. However, it is relevantly higher among the elderly since it can cause incapacity, injuries and even death. Its social cost 
is high, and it can be even higher when the elderly person begins to present more dependency, or even the need to be institutionalized ${ }^{6}$. According to the report of the World Health Organization (WHO) about preventing falls among the elderly ${ }^{7}$, the number of falls increases much with the increasing number of older adults in many nations of the world; therefore, preventing falls is a challenge to population aging.

Falls among the elderly are relevant in national statistics, once they were the third cause of death in the set of external causes in 2007, and the first reason for hospital admissions among the elderly population in 2008 , both for men and women, with a $14.0 / 100,000$ coefficient $(15.7 / 100,000 \text { for men and } 12.5 / 100,000 \text { for women })^{8}$. In the United States, mortality rates resulting from falls for people aged more than 65 years old are higher in relation to Brazil, representing 36.8/100,000 (46.2/100,000 for men and $31.1 / 100,000$ for women $)^{9}$.

Falls among the elderly are considered to be a multifactorial event, and their determining factors can be attributed to intrinsic factors, which belong to the individual, and extrinsic factors, which derive from social and environmental aspects ${ }^{6,10}$.

The theme has shown results addressed to the characteristics of the falls, as well as their causes and the consequences. However, there is little discussion about the gender differences involving falls among the elderly.

In a literature review about the theme ${ }^{11}$, the authors found contradictory results in several data bases concerning the proportion of falls with regard to gender. Four studies were identified that reported women as being mostly affected by falls. Only one study indicated men were more prone to falling. Some studies show this difference exists, but they do not analyze the aspects related to it deeply $y^{6,12-15}$. In this research, it was chosen to use the term gender since it is related to the social structure of sex, that is, the aggregation of costumes, cultures, social values and behavioral models, unlike sex, which characterizes the anatomic structure of the being ${ }^{16}$.

Considering the importance of falls in the elderly population, it is essential that these individuals have access to care in pre-hospital services that are organized and integrated to health services. This service contributes significantly with the reduction of the number of deaths, and it also decreases, or even eliminates, the sequels and the consequences caused by the injuries.

Therefore, besides being essential to improve the prognosis of the victims, prehospital services represent an important source of data and information, thus enabling the analysis of several aspects of trauma.

Considering the specificities of falls, the conduction of studies in the gender perspective with the objective of subsidizing policies and programs related to the prevention of this event is justified. Therefore, this study aimed at identifying elderly people who were victims of falls, according to gender, who were assisted by pre-hospital services in the city of Maringá, Paraná, Brazil. 


\section{METHODS}

It is an exploratory cross-sectional study conducted in the city of Maringá, Paraná, Brazil, located in the North-Central mesoregion of Paraná, with a population of 357,117 inhabitants, according to the census of $\mathrm{IBGE}^{17}$. The study population consisted of people aged 60 years old or more who suffered falls in the urban perimeter of the city from 2006 to 2008 , and received pre-hospital care.

Pre-hospital care in the city is conducted by the Integrated Care Service to Trauma and Emergency (SIATE), by means of the Firefighter team of the State of Paraná since 1997, and by the Mobile Urgent Care service (SAMU), created in 2004.

The study included elderly people who suffered falls in the city of Maringá from 2006 to 2008 and who were assisted by SAMU and SIATE. In this study, elderly people were those aged 60 years old or more, as disposed in the first article of the Elderly Statute, Law $10,741 / 2003^{18}$.

Data were collected from the fill out form from SAMU and the Digital Data Base System from SIATE, the SYSBM, a worksheet from Excel elaborated for this purpose. The period of data collection lasted six months, beginning in July 2009 and ending in January 2010. The study population was constituted of 1,444 occurrences involving elderly people, being 737 men and 707 women who suffered falls in the urban perimeter of Maringá. Out of these 1,444 occurrences, there has been more than one intercurrence with the same individual in the studied period; 34 elderly people presented two occurrences, three elderly people presented three occurrences and one elderly person presented four occurrences.

The analyzed variables were: gender (male and female); age group (60 to 69 years old, 70 to 79 years old and 80 years old or more); alcohol breath (presence and absence); type of fall (same level and higher level); time of fall (00:00 to 05:59, 06:00 to 11:59, 12:00 to 17:59 and 18:00 to 23:59); day of the week (weekday and weekend); place of fall (home, street and other places); referral to hospital (yes or no); value in the Glasgow coma scale (GCS) (mild, moderate and severe); value in the Revised Trauma Score (RTS) (mild, moderate and severe); number of injuries (1, 2, 3, 4- 5, 6 injuries or more); type of injury (cut-blunt injury, perforating injury, contusion, excoriation, fracture, luxation and other lesions) and location of injury (head, neck, thorax, abdomen-pelvis-back, upper and lower limbs).

It is important to clarify that the variable presence of alcohol breath is a subjective measure, since it refers to the perception/observation of one or more physicians on duty at the time of care.

Fall severity was assessed by the GCS, the RTS and the number of lesions. GCS and RTS are physiological trauma indexes that are based on vital data, level of consciousness and other associated physiological variables, which provide a fast general picture of the victim. The GCS considers ocular opening, the best verbal response and the best motor response, and the sum of the value attributed to each indicator can reach up to 
15 points. GCS scores are subdivided in 3 intervals: between 13 and 15 (mild traumatic brain injury (TBI)), 9 to 12 , (moderate TBI), and 0 to 8 (severe TBI) ${ }^{19}$.

In order to assess RTS, three indicators were used: FCS, systolic blood pressure and respiratory frequency. The sum of these indicators can reach up to 12 points. Traumas are subdivided in three intervals: victims with RTS between 11 and 12 (mild trauma), 8 to 10 (moderate trauma) and 0 to 7 (severe trauma) ${ }^{20}$.

Data were tabulated by the Epi Info $6.04 \mathrm{~d}^{\circledR}$ software and analyzed after double-typing, comparison and correction ${ }^{21}$. In order to compare the characteristics of falls with regard to gender, the $\chi^{2}$ test was used with a 0.05 significance level.

This study was approved by the Permanent Human Research Ethics Committee of Universidade Estadual de Maringá (report n. 590/2009).

\section{RESULTS}

The results of this study showed prevalence in the assistance conducted by SIATE, corresponding to $58.7 \%$, while SAMU took care of $41.3 \%$ of the occurrences. Concerning gender, a higher percentage of falls was observed in the male population $(51.0 \%)$.

In Table 1 , it is possible to verify significant difference $(\mathrm{p}<0.001)$ when compared to age group and presence of alcohol breath in relation to the gender of the elderly. There has been a higher percentage of falls in the male population aged from 60 to 69 years old $(42.7 \%)$, and this percentage decreases progressively in older age groups. As to females, the age group from 60 to 69 years old has the lower percentage of falls $(27.9 \%)$, and similar and higher frequencies begin to occur in older age groups. During care, the presence of alcohol breath was mostly noticed among men (14.4\%) than women $(1.1 \%)$.

Table 1. Elderly people who suffered falls by age group and alcohol breath. Maringá, 2006 to 2008.

\begin{tabular}{|c|c|c|c|}
\hline \multirow{2}{*}{ Variable } & Male $(n=737)$ & Female $(n=707)$ & \multirow{2}{*}{$\mathrm{p}$-value } \\
\hline & $\mathrm{n}(\%)$ & n (\%) & \\
\hline \multicolumn{4}{|c|}{ Age group $(n=1444)$} \\
\hline $60-69$ & $315(42.7)$ & $197(27.9)$ & $<0.001$ \\
\hline $70-79$ & $262(35.6)$ & $256(36.2)$ & \\
\hline$\geq 80+$ & $160(21.7)$ & 254 (35.9) & \\
\hline \multicolumn{4}{|c|}{ Alcohol breath $(n=1444)$} \\
\hline Yes & $106(14.4)$ & $8(1.1)$ & $<0.001$ \\
\hline No & $631(85.6)$ & 699 (98.9) & \\
\hline
\end{tabular}


In Table 2 , it is possible to observe significant differences $(p<0.001)$ concerning the type of fall. In both genders, falls at the same level were prevalent. However, there was a higher percentage among females, while falls at higher levels were more frequent among men. As to the time of occurrences, they took place mostly during the day (morning and afternoon) for both genders. Falls were prevalent during weekdays. With regard to place of occurrence, differences were significant $(\mathrm{p}<0.001)$. The most common place was the household, and women fell more in their homes than men. It is also possible to verify the expressive frequency of men who fell on the street.

Table 3 presents the indicators of severity. Out of the 1,444 elderly people assisted, 1,347 $(95.3 \%)$ were conducted to hospitals. In 59 cases (4.2\%), there was no need for referral, or the elderly refused to go to the hospital, and eight $(0.6 \%)$ died at the place of occurrence or during pre-hospital care. It is worth to mention there was a significant difference $(\mathrm{p}<0.023)$ as to referral to hospital. In the GCS and the RTS analyses, most elderly people presented mild level in both scales, with significant difference for GCS.

Table 2. Characteristics of falls in the elderly. Maringá, 2006 to 2008.

\begin{tabular}{|c|c|c|c}
\multirow{2}{*}{ Variable } & Male $(n=737)$ & Female $(n=707)$ & \multirow{2}{*}{$p$-value } \\
\cline { 2 - 3 } & $n(\%)$ & $n(\%)$ &
\end{tabular}

Type of fall $(n=1381)$

\begin{tabular}{|c|c|c|c|}
\hline Same level & $553(78,3)$ & $623(92,3)$ & $<0,001$ \\
\hline High level & $153(21,7)$ & $52(7,7)$ & \\
\hline \multicolumn{4}{|l|}{ Time $^{\#}(n=1430)$} \\
\hline 00:00 - 05:59 & $25(3,4)$ & $34(4,9)$ & 0,439 \\
\hline $06: 00-11: 59$ & $249(34,2)$ & $249(35,5)$ & \\
\hline $12: 00-17: 59$ & $298(40,9)$ & $266(37,9)$ & \\
\hline $18: 00-23: 59$ & $157(21,5)$ & $152(21,7)$ & \\
\hline \multicolumn{4}{|c|}{ Days of the week $(n=1444)$} \\
\hline Weekday & $555(75,3)$ & $522(73,8)$ & 0,546 \\
\hline Weekend & $182(24,7)$ & $185(26,2)$ & \\
\hline \multicolumn{4}{|l|}{ Place $^{\#}(n=1323)$} \\
\hline Home & $341(50,4)$ & $443(68,6)$ & $<0,001$ \\
\hline Streets & $228(30,7)$ & $143(22,1)$ & \\
\hline Other locations & $108(15,9)$ & $60(9,3)$ & \\
\hline
\end{tabular}

\#The difference between the observed and the total number refers to non reported data. 
Table 3. Indicators of severity of falls in the elderly. Maringá, 2006 to 2008.

\begin{tabular}{|c|c|c|c|}
\hline \multirow{2}{*}{ Variable } & Male $(n=737)$ & Female $(n=707)$ & \multirow{2}{*}{$\mathrm{p}$-value } \\
\hline & $\mathrm{n}(\%)$ & $\mathrm{n}(\%)$ & \\
\hline \multicolumn{4}{|c|}{ Referred to hospital $(n=1406)^{\# 5}$} \\
\hline Yes & $675(94,5)$ & $672(97,1)$ & 0,023 \\
\hline No & $39(5,6)$ & $20(2,9)$ & \\
\hline \multicolumn{4}{|c|}{ Glasgow Come Scale $(n=1407)^{\#}$} \\
\hline Mild (13-15) & $679(94,7)$ & $671(97,3)$ & 0,046 \\
\hline Moderate $(9-12)$ & $21(2,9)$ & $9(1,3)$ & \\
\hline Severe $(3-8)$ & $17(2,4)$ & $10(1,4)$ & \\
\hline \multicolumn{4}{|c|}{ Revised Trauma Score $(n=1341)^{\#}$} \\
\hline Mild (11-12) & $652(95,9)$ & $643(97,3)$ & 0,291 \\
\hline Moderate $(8-10)$ & $19(2,8)$ & $14(2,1)$ & \\
\hline Sevre $(0-7)$ & $9(1,3)$ & $4(0,6)$ & \\
\hline \multicolumn{4}{|c|}{ Number of injuries ${ }^{\S}(n=1117)$} \\
\hline 1 & $263(45,4)$ & $298(55,4)$ & 0,014 \\
\hline 2 & $171(29,5)$ & $139(25,8)$ & \\
\hline 3 & $88(15,2)$ & $56(10,4)$ & \\
\hline $4-5$ & $49(8,5)$ & $39(7,3)$ & \\
\hline 6 and more & $8(1,4)$ & $6(1,1)$ & \\
\hline
\end{tabular}

\#The difference between the observed and the total number refers to non reported data; ${ }^{\star} 321$ cases were excluded for presenting no lesion; ${ }^{\S}$ Eight deaths that occurred at or during pre-hospital care were excluded.

Concerning the number of injuries, it was possible to observe statistically significant differences $(\mathrm{p}=0.014)$. The occurrence of injuries was more frequent among women (55.4\%); as for men, higher percentages were observed in all of the categories.

Table 4 presents the types of injuries suffered by the elderly as a result of the falls and the place where they occurred. With regard to the type of lesion, some specificities were identified among men and women, with statistically significant differences $(\mathrm{p}<0.001)$. Among men, the most common types of lesions were the cut-blunt injuries (CBI), with $35.0 \%$, followed by contusions, with $34.5 \%$. Among women, the most common types of injuries were contusions (31.3\%), followed by excoriations $(26.5 \%)$. When comparing men 
Table 4. Characteristics of injuries resulting from falls among the elderly. Maringá, from 2006 to 2008.

\begin{tabular}{|c|c|c|c|}
\hline \multirow{2}{*}{ Variable } & Male $(n=737)$ & Female $(n=707)$ & \multirow{2}{*}{ p-value } \\
\hline & n (\%) & $\mathrm{n}(\%)$ & \\
\hline \multicolumn{4}{|l|}{ Type of injury" $(n=1639)$} \\
\hline Cut-blunt injury & $278(35,0)$ & $157(18,6)$ & \multirow{7}{*}{$<0,001$} \\
\hline Perforating injury & $4(0,5)$ & $4(0,5)$ & \\
\hline Contusion & $274(34,5)$ & $264(31,3)$ & \\
\hline Excoriation & $135(17,0)$ & $224(26,5)$ & \\
\hline Fracture & $56(7,0)$ & $144(17,1)$ & \\
\hline Luxation & $17(2,1)$ & $12(1,4)$ & \\
\hline Other injuries & $31(3,9)$ & $39(4,6)$ & \\
\hline \multicolumn{4}{|l|}{ Place of injury $(n=1650)$} \\
\hline Head (skull and face) & $403(44,7)$ & $227(30,3)$ & \multirow{6}{*}{$<0,001$} \\
\hline Neck & $2(0,2)$ & $10(1,3)$ & \\
\hline Thorax & $35(3,9)$ & $29(3,9)$ & \\
\hline Abdomen, pelvis and back & $67(7,4)$ & $73(9,8)$ & \\
\hline Upper limbs & $209(23,2)$ & $212(28,3)$ & \\
\hline Lower limbs & $186(20,6)$ & $197(26,4)$ & \\
\hline
\end{tabular}

\#Admits more than one answer.

and women as to the occurrence of fractures, it is possible to observe that women were considerably more affected.

With regard to the location of the injury, differences were statistically significant ( $p<0,001)$. Even though the head was the most affected region both for men and for women, a higher frequency was observed among men (44.6\%). Lower and upper limb injuries were relatively more common among women.

\section{DISCUSSION}

According to the found results, the higher percentage of care performed by SIATE can be explained by an older service and by the characteristic of the service that it has been performing with time, being mostly addressed to trauma victims. 
As observed in the results of this study, the percentage differences of falls with regard to gender are very small ( $51.0 \%$ for men and $49.0 \%$ for women), unlike the studies that show the prevalence of falls among women ${ }^{15,22-25}$. It is worth to mention that the studies that investigate this condition in the elderly population are mostly conducted in the community and in long stay institutions $s^{15,25-28}$. In literature, studies analyzing the elderly victims with trauma caused by falls and assisted by pre-hospital service are scarce. With regard to the percentage of elderly women who suffered falls and who were assisted by pre-hospital service verified in this study, it is not possible to establish an association with the lower incidence of falls among women. The factors that determine this behavior deserves to be investigated in further studies.

Even though the proportion of falls among males and females presented approximated values, the data in this study showed that the behavior of falls among men and women is different in some aspects. With regard to age group, differences were significant. The male gender presented higher percentage of falls at the age group of $60-69$ years old, which reduces with age. As to the female gender, the age group of $60-69$ years old was the least affected one, and the percentage of falls was higher for older ages. These data are similar to the ones from a study conducted with a sample of 24 emergency units in the state of São Paulo, which verified that the male gender presented higher percentage of falls in the age groups of $60-69$ years old, decreasing with age, and the inverse was observed for the male gender ${ }^{13}$. Other studies found higher prevalence of falls at older ages, both for females and males ${ }^{6,14-15}$.

The gender approach in epidemiological studies about falls becomes important to understand the risk factors, once these are multicausal. Even though the mortality caused by falls was not the focus of this study, literature shows that rates of fatal falls among men overcome those of women in all age grouops ${ }^{23}$, which can be attributed to the fact that men suffer from higher comorbidity conditions than women at the same age group'.

The higher probability of men getting involved with intense and dangerous physical activities and risky behaviors, such as climbing high stairs, cleaning roofs of houses or ignoring the limits of physical boundaries ${ }^{7}$, can explain the higher mortality caused by falls among elderly men, as well as the highest incidence of falls at younger age groups of the elderly, unlike the behavior of falls among women.

In this study, the significant difference of alcohol use was observed, with higher proportions for the male population. The use of alcohol is usually observed in elderly people and, even if taken for granted, it deserves attention due to the constant increase of this population. After getting older, this population tends to become more prone to alcohol intoxication in smaller doses in relation to those tolerated in the past ${ }^{29}$.

The prevalence of alcohol use by male elderly people was also found in a study conducted in São Paulo, which correlated the use of alcohol and falls among the elderly. In this study, the intake of alcohol was compared between genders, and the percentage of abstinence among women $(68.4 \%)$ was higher in relation to the same percentage among 
men $(23.6 \%)^{30}$. A literature review about alcohol-related disorders among elderly people showed prevalence of $18 \%$ in hospital and infirmary admissions, of 23 to $44 \%$ in psychiatric units, of $14 \%$ in hospital emergency rooms and of $10 \%$ in the general community. A higher prevalence was observed in the male population, with higher risk of falls of up to $10.6 \%$ among elderly who consumed alcohol ${ }^{31}$.

As to the type of fall, the ones at the same level were more common, both for men and women, which is in accordance with data found in literature ${ }^{13,14,27}$. In a study conducted in the city of São Paulo, which correlated falls and death among the elderly, $47.4 \%$ of the occurrences corresponded to falls at the same level ${ }^{13}$. These falls are usually associated with physiological changes that take place in the aging process, such as decreased visual acuity, decreased motor strength, difficulties to move, and also factors related to the environment ${ }^{32}$. However, in this study falls at the same level were significantly higher among females, and the inverse was observed for males. As previously explained, this result is believed to be owed to the fact that men are more involved in intense and dangerous physical activities, unlike women, who stay at home performing household chores.

Falls in this study happened mostly during the day, being more common in the afternoon, with similar percentage distribution when men and women are compared. The higher frequency of falls during the day was also observed in a study conducted with institutionalized elderly people in Rio de Janeiro ${ }^{33}$, and this fact can be associated to the higher number of tasks performed by the people during the day. The same was not observed in another study, which analyzed elderly people who were victims of falls and assisted by the firefighter team of the city of São Paulo. This study found more falls at night (40.42\%), followed by the afternoon. This study associated falls at night to sleep disorders and to functional decline with deficit in physiological functions, which increase the number of falls at night ${ }^{34}$.

Accidents caused by falls in this study were more frequent during weekdays, with no significant differences between men and women. Literature that mentions falls among the elderly mentions no data referring the days on which these events occurred ${ }^{2-4,9,11,26,28-29,34}$.

The study showed that the most frequent place of falls was in the house, both for men and for women. These results are similar to data in other studies, which show that falls are more frequent in the households $s^{3,6,13-14}$. Studies conducted only with women also identified the household as the most frequent place for falls ${ }^{10,26}$.

Falls in the household were more frequent both for men and for women. Differences were significant, with higher percentage of women suffering falls in the household (68.6\%) when compared to men (50.4\%). Falls in the street were more prevalent among men $(30.7 \%)$. This result can be associated with the characteristics that are inherent to the gender.

Even though the occurrence of falls in the streets presented lower frequency in relation to the household, the conditions of the street (broken and irregular sidewalks, insufficient lights) can be an important factor leading to falls, therefore, they should be considered by the 
public policies. The identification of the place of fall is essential to recognize the associated risk factors and the formulation of preventive measures.

Most of the elderly patients (95.8\%) assisted by the pre-hospital team was referred to hospitals in the city of Maringá. Concerning gender, there was a significant difference in referrals $(\mathrm{p}=0.023)$, and the percentage of women $(97.1 \%)$ was slightly higher than the percentage of men $(94.5 \%)$. The frequency of referrals for hospital care is expected, once victims assisted in the pre-hospital period should be referred for evaluation in the hospitals.

Even though this study did not show the percentage of medical care at the place of occurrence, as well as the hospital admission percentage, data from SIH/SUS ${ }^{35}$ estimate that $55.5 \%$ of the elderly people were hospitalized (50.1\% of men and $60.9 \%$ of women). This inference is possible once the pre-hospital services refer victims to public hospitals and the ones who are integrated with SUS in Maringá.

At analysing the GCS, a significant difference was observed for men and women ( $p=0.046)$, and $5.1 \%$ of the men presented with trauma classified as moderate and severe; as for women, this percentage was of $2.7 \%$. GCS is used with the objective of assessing the severity of the TBI, with major correlation with the prognosis of the patient ${ }^{19}$.

Most elderly people assisted by the pre-hospital services presented RTS classified as mild ( $4.1 \%$ for men and $2.7 \%$ for women). RTS is widely used in pre-hospital care, since it is easy to use at the place of occurrence and because it enables the assessment of the severity of the trauma, the adequate screening of cases for the hospital of destination and also the evaluation of physiological status at the different stages of care $^{20}$. Among the elderly, these rates can be inadequate to predict mortality, especially when lesions are less severe. Even in cases that present low trauma rates, the assistance to the traumatized elder should not be reduced ${ }^{36}$.

Some of the observed results enabled to conclude that falls were more severe among men, since they presented higher percentage of falls at higher levels and higher moderate and severe scores in the GCS and the RTS. These data reinforce the fact that men are more prone to more severe falls due to the risky behavior they adopt, as aforementioned. Another important aspect that determines higher mortality caused by falls among men is attributed to the fact that men suffer more from comorbidity conditions than women at the same age group 9 .

Among the elderly in this study, women were the ones who mostly suffered injuries caused by falls. In literature about this subject, there are no studies relating injuries to gender. However, studies analyzing victims of external causes, which include falls, point out that men are the ones with more lesions ${ }^{27,37}$.

As to the types of injuries caused by falls, fractures are mostly valued in the existing studies $^{2-3,9,25-26,28,34}$, and other types of injury are not emphasized. In this study, the most commonly found types of lesion are superficial ones, like injuries, contusions and excoriations, which is similar to a study conducted with elderly people who were victims of trauma in an emergency unit of a university hospital in Campinas ${ }^{24}$. 
In the current scenario, among the injuries resulting from falls, fractures corresponded to $70 \%$ of the deaths caused by accidents among elderly people aged more than 75 years old. They have a ten times higher rates of hospitalizations and eight times more deaths as consequences of falls when compared to children, who also present high frequency of falls ${ }^{38}$.

In this study, the incidence of fractures was higher among females. A study conducted in Ribeirão Preto also indicated women as being mostly affected by fractures (70\%) in relation to men $(53 \%)^{6}$. In a study conducted with users of basic health units, a percentage of $12.1 \%$ of fractures was found among the elderly who suffered falls ${ }^{15}$.

The higher incidence of fractures among women may be related to older age and low bone mineral density, which leads to osteoporosis, especially among women in the postmenopause period ${ }^{10,39-40}$. The occurrence of fractures is a matter of concern in the elderly population due to the difficulties to recover and to vulnerability, as well as to the consequent hospitalization, which keeps the person in bed for long periods. This can lead to pressure ulcers to lung complications ${ }^{39}$. Besides, most of them end up affected by incapacity resulting from this event, therefore requiring special care.

With regard to the topography of lesions, the head was the prevalent location, followed by injuries in the upper and lower limbs. A study analyzing falls among the elderly assisted by a pre-hospital service showed that the upper limbs were mostly affected by injuries ${ }^{34}$.

\section{FINAL CONSIDERATIONS}

By analyzing falls among men and women who received pre-hospital care, it was possible to identify some specificities, especially the higher proportion of falls among older women. The opposite was observed for men, but the presence of alcohol breath was considerably more frequent among men. Falls at the same level were significantly higher for females, unlike males, who presented more frequency of falls at higher levels. As to the location of the fall, there was statistically significant difference, being more prevalent in the household for the women. As for men, the street was a more common location. Fractures were significantly more present among women.

Finally, some limitations of this study should be emphasized. Probably, the sources of data did not approach the completeness of occurrences, once some of them are not notified to organs in charge. Sometimes, victims are assisted by other people involved in the event. A few studies discuss the gender differences related to the occurrence of falls among the elderly population, as well as pre-hospital care, which in a way made the analysis of the found results more difficult. Another important aspect to be considered refers to the analysis of the presence of alcohol breath at the time of care, since it is a subjective measure that depends on the perception of the professionals on duty at the time of assistance. 
The found results show the multiple dimensions of occurrences involving elderly people who suffered falls, and reinforce the need for further studies in this field to serve as a base for the formulation of public policies related to preventing falls, emphasizing gender differences.

\section{REFERENCES}

1. Alves JE. O inevitável envelhecimento da população brasileira. Instituto de Economia da UFRJ [Internet]. Rio de Janeiro (RJ); 2008. Disponível em: http: / / www. ie.ufrj.br/aparte/pdfs/o_inevitavel_envelhecimento. pdf. (Acessado em 14 de abril de 2009).

2. Siqueira RL, Botelho MI, Coelho FM. A velhice: algumas considerações teóricas e conceituais. Ciênc Saúde Coletiva 2002, 7(4): 899-906.

3. Ribeiro AP, Souza ER, Atie S, Souza AC, Schilithz AO. A influência das quedas na qualidade de vida de idosos. Ciênc Saúde Coletiva 2008, 13(4): 1265-73.

4. Organização Mundial da Saúde. Classificação estatística internacional de doenças e problemas relacionados à saúde. 10ª Revisão. São Paulo; 2003 (Centro Colaborador da OMS para a Classificação de Doenças em Português).

5. Moura RN, Santos FC. Quedas em idosos: fatores de risco associados. Gerontol 1999, 7(2): 15-21.

6. Fabrício SC, Rodrigues RA, Costa Junior ML. Causas e consequências de quedas de idosos atendidos em hospital público. Rev Saúde Pública 2004, 38(1): 93-9.

7. Secretaria de Estado da Saúde [Internet]. Relatório Global da OMS sobre prevenção de quedas na velhice. São Paulo (SP); 2010. Disponível em: http:/ / bvsms. saude.gov.br/bvs/publicacoes/relatorio_prevencao_ quedas_velhice.pdf. (Acessado em agosto de 2012).

8. Gawryszewski VP, Jorge MHP, Koizumi MS. Mortes e internações por causas externas entre os idosos no Brasil: o desafio de integrar a saúde coletiva e atenção individual. Rev Assoc Med Bras 2004, 50(1): 97-103.

9. Stevens JA, Ryan G, Kresnow M. Fatalities and injuries from falls among older adults - United States, 1993-2003 and 2001-2005. JAMA 2007, 297(1): 32-3.

10. Silva RB, Costa-Paiva L, Oshima MM, Morais SS, PintoNeto AM. Frequência de quedas e associação com parâmetros estabilométricos de equilíbrio em mulheres na pós menopausa com e sem osteoporose. Rev Bras Ginecol Obstet 2009, 31(10): 496-502.

11. Gama, ZA; Gomez-Cónesa, A. Factores de riesgo de caídas en ancianos: revisión sistemática. Rev Saúde Pública 2008, 42(5): 946-56.
12. Barbosa SR. Identificação de fatores de risco para quedas em idosos, distintos por gênero e idade [tese de doutorado] Uberlândia: Faculdade de Engenharia Elétrica, Universidade Federal de Uberlândia; 2008.

13. Gawryszewski VP. A importância das quedas no mesmo nível entre idosos no estado de São Paulo. Rev Assoc Med Bras 2010, 56(2): 162-7.

14. Schiaveto FV. Avaliação do risco de quedas em idosos na comunidade [dissertação de mestrado] São Paulo: Escola de Enfermagem de Ribeirão Preto da Universidade de São Paulo; 2008.

15. Siqueira FV, Facchini LA, Piccini RX, Tomasi E, Thumé E, Silveira DS et al. Prevalência de quedas em idosos e fatores associados. Rev Saúde Pública 2007, 41(5): 749-56.

16. Carloto CM. O conceito de gênero e a sua importância para a análise das relações sociais. Serv Social em Revista 1998, 3(2): 201-13.

17. Instituto Brasileiro de Geografia e Estatística. Censo demográfico: resultado final. [Internet] Paraná (SC); 2010]. Disponível em: http://www.ibge.gov.br/ home/estatistica/populacao/censo2010/tabelas_pdf/ total_populacao_parana.pdf. (Acessado em janeiro de 2012).

18. Ministério da Saúde. Lei $n^{\circ} 10.741$, de $1^{\circ}$ de outubro de 2003. Dispõe sobre o estatuto do idoso e dá outras providências. [Internet] Brasília (DF); 2003 Disponível em: http://portal.saude.gov.br/ portal/arquivos/ pdf/p10741_estatuto_do_idoso.pdf. (Acessado em abril de 2009).

19. Gabbe BJ, Cameron PA, Finchi CF. The status of the Glasgow Coma Scale. Emerg Med 2003, 15(4): 353-60.

20. Champion HR, Sacco WJ, Copes WS, Gann DS, Gennarelli TA, Flanagan ME. A revision of the trauma score. J Trauma 1989, 29(5): 623-9.

21. Epi Info: a word-processing, database, and statistics program for public health on IBM compatible microcomputers [computer program]. Version 6.04. Atlanta (USA): Centers for Disease Control and Prevention, Atlanta; 1995. 
22. Zecevic AA, Salmoni AW, Speechley M, Vandervoort AA. Defining a fall and reasons for falling: comparisons among the views of seniors, health care providers, and the research literature. Gerontologist 2006; 46(3): 367-76.

23. Blake AJ, Morgan K, Bendall MJ, Dallosso H, Ebrahim SB, Arie TH et al. Falls by elderly people at home: prevalence and associated factors. Age Ageing 1988, 17(6): 365-72.

24. Lima RS, Campos ML. Perfil do idoso vítima de trauma atendido em Unidade de Urgência e Emergência. Rev Esc Enferm USP 2011, 45(3): 659-64.

25. Lopes KT, Costa DF, Santos LF, Castro DP, Bastone AC. Prevalência do medo de cair em uma população de idosos da comunidade e sua correlação com mobilidade, equilíbrio dinâmico, risco e histórico de quedas. Rev Bras Fisioter 2009, 13(3): 223-9.

26. Lopes MC, Violon MR, Lavagnoli AP, Marcon SS. Fatores desencadeantes de quedas no domicílio em uma comunidade de idosos. Cogitare Enferm 2007, 12(4): 472-7.

27. Biazin DT, Rodrigues RA. Profile of elderly patients who suffered trauma in Londrina - Paraná. Rev Esc Enferm USP 2009, 43(3): 599-605.

28. Browning C, Hill K, Kendig H, Osborne D. Gender issues in falls in older community dwelling adults. Aust J Prim Health 1998, 4(3): 222-8.

29. Rigo JC, Rigo JF, Faria BC, Stein A, Santos VM. Trauma associado com uso de álcool em idosos. Brasilia Méd 2005, 42(1/2): 35-40.

30. Lima MC, Simão MO, Oliveira JB, Cavariani MB, Tucci AM, Kerr-Correa F. Alcohol use and falls among the elderly in Metropolitan São Paulo, Brazil. Cad Saúde Pública 2009, 25(12): 2603-11.

31. O'Conell H, Chin AV, Cunningham C, Lawlor B. Alcohol use disorders in elderly people - redefining an age old problem in old age. BMJ 2003, 327(7416): 664-7.

32. Perracini MR, Ramos LR. Fatores associados a quedas em uma coorte de idosos residentes na comunidade. Rev Saúde Pública 2002, 36(6): 709-16.
33. Coutinho ES, Bloch KV, Rodrigues LC. Characteristics and circumstances of falls leading to severe fractures in elderly people in Rio de Janeiro, Brazil. Cad Saúde Pública 2009, 25(2): 455-9.

34. Coiado, CR, Amaral AF, Santos RR. Incidência de quedas na população idosa no âmbito domiciliar: atendimento Sistema 193. Saúde Coletiva 2009, 6(27): 19-23.

35. Ministério da Saúde [Internet]. Secretaria Executiva. Datasus [cited Apr 2012]. Acesso à base de dados do Sistema de Informação Hospitalar. Available from: http: //www2.datasus.gov.br/DATASUS / index.php

36. Parreira JG, Soldá SC, Perlingeiro JA, Padovese CC, Karakhanian WZ, Assef JC. Análise comparativa das características do trauma entre pacientes idosos e não idosos. Rev Assoc Med Bras 2010, 56(5): 541-6.

37. Mesquita Filho M, Jorge MH. Características da morbidade por causas externas em serviço de urgência. Rev Bras Epidemiol 2007, 10(4): 679-91.

38. Paranhos WY. Emergências e Urgências Geriátricas. In: Calil AM, Paranhos WY. O enfermeiro e as situações de emergência. São Paulo: Atheneu; 2007. p. 731-40.

39. Rodrigues RA, Mendes MM. Prevenindo Acidentes Domiciliares. In: Duarte YA, Diogo MJ. Atendimento Domiciliar: um enfoque gerontológico. São Paulo: Atheneu; 2005. p. 19-26.

40. Barros-Filho TE, Napoli MM. Aspectos ortopédicos e traumatológicos. In: Carvalho-Filho ET, Netoo MP. Geriatria: Fundamentos, Clínica e Terapêutica. São Paulo: Atheneu; 2000. p. 319-327.

Received on: 01/10/2012

Final version presented on: 09/09/2012

Accepted on: 10/13/2012 